\title{
Micro Financial Sharia Non-bank Strategic Analysis: a Study at BMT Beringharjo, Yogyakarta
}

\author{
Marissa Grace Haque $^{1}$, Nurjaya ${ }^{2}$, Azhar Affandi $^{3}$, Heri Erlangga ${ }^{4}$, Denok Sunarsi ${ }^{5}$ \\ ${ }^{1}$ STIE Indonesia Banking School, Jakarta Selatan, Indonesia \\ ${ }^{2}$ Universitas Suryakancana, Cianjur, Jawa Barat, Indonesia \\ ${ }^{3.4}$ Universitas Pasundan, Bandung, Jawa Barat, Indonesia \\ ${ }^{5}$ Universitas Pamulang, Tangerang Selatan, Banten, Indonesia \\ marissa.haque@ibs.ac.id
}

\section{Abstract}

Prior to the 1998 economic downfall, and in ten years after in 2008, BMT (Baitul Maal wa Tamwil) proofed the endurance to remain stable. From those external factors, strived the company very hard hard to sustain its business, as well as to formulate a better strategy to its competitive advantage. The research begins with the internal and external analysis, using a SWOT Analysis. The results shows its business strength and its market penetration, lies in its company's human development. Through the IE Matrix, founds BMT Beringharjo competitive position in Quadrant or cell IV Matrix IE, with growth strategy through horizontal integration concentration. Based on its position of: (1) competition; (2) strength; (3) weakness; (4) opportunity; (5) threats. Enriched with strategy of: (1) market penetration; (2) market development; as well as (3) horizontal integration strategy to the creative innovation strategy is inevitable to remain exist and gain more success.
Keywords

$\mathrm{BMT}$; strategic management; SMOT Matrix, IEMatrix, BOG four-step strateav

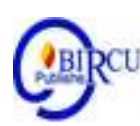

\section{Introduction}

The vast growing industry of Indonesia's sharia economic development could not be separated from the fact that 80 percent of Indonesia's population were Muslims. Prior to the 1998 economic downfall, and with almost the same condition in ten years after in 2008, midst of the liberalization of the macroeconomic storm, players of sharia non-bank microeconomics business or BMT (Baitul Maal wa Tamwil) have the endurance to remain stable as well as run sustainably. Unfortunately, the situation had created high competition manner among players. From the external factor, it influences BMT Beringharjo to strive to be able to sustain its business. The condition mentions, strive BMT Beringharjo to be able to formulate a new strategy upon its competitive advantage.

\section{Research Objective}

The purpose of this study is to support its stakeholders to see in a much clearer manner the potential of other financial institutions other than banks. More specifically, to its micro-financial non-bank institutions, which are based on the Islamic moral values, which is dedicated to those who never had or only have very little chance of being accessed by banks.

Since Lakshmi and Visalakshmi (2003) stated that the main weakness of microfinancial non-bank institutions and cooperatives derived from their governance, it is 
arguable that the same situation generally also happened in Indonesia. BMT Beringharjo's governance will give us a different perspective on what a simple strategic management system needs to be implied, and seek some solutions to its problem in a more comprehensive way. Starts from the input stage approach to see and assess the external condition follows by the internal factor to be analyzed to see its competitive profiles and get some key success factors. Furthermore, follows with a phase match with a match analysis of External and internal conditions that produce several strategy alternatives, as well as the stage of decision making in planning the best strategy to win the competition. This study specifically aims to find a strategy that fits BMT Beringharjo in a business condition manner, in a sense of Indonesian sharia non-bank micro-economic development, to support Sustainable Development Goals (SDGs) on its important element that financial inclusion has been given significant prominence in reform and development agendas proposed by the United Nations and G-20. And more specifically is due to the significance of Islamic financial institutions which goes beyond improved access to finance, to enhanced access to: (1) savings; and (2) risk mitigation products, as well as social inclusion that allows individuals and companies to engage more actively in the real economy, which represents one of the very important drivers to the economic growth.

\section{Review of Literature}

Employees who have skills in emotional intelligence will be able to read other people's feelings and have social skills which means they are able to manage the feelings of others well. Very emotional intelligence important is owned by every employee in an organization that will help employees connect with other employees and share information and to manage conflicts that arise in carrying out tasks in their work (Siregar, 2020). In such unsetting moments, we often forget that stressors, if not escapable, are fairly manageable and treatable. Stress management refers to interventions designed to reduce the impact of stressors in the workplace. These can have an individual focus, aimed at increasing an individual's ability to cope with stressors (Orji, 2020). Every company always tries to maximize the benefits it gets. Various strategies are applied to achieve these goals. The company will always keep its performance looking good in the eyes of its stakeholders. But in reality, companies are often faced with various obstacles that can cause a decline in performance and even financial difficulties and eventually go bankrupt. And of course the company will try to cover up this unhealthy condition from its stakeholders (Sitanggang et al, 2020).

Nag, R.; Hambrick, D. C.; Chen, M.-J (2007) mentioned what a strategic management is, that in management field where strategic management involves the formulation and implementation of the major goals and initiatives taken by an organization's managers on behalf of stakeholders, based on consideration of resources and an assessment of the internal and external environments in which the organization operates, inductively derivation of a consensus definition of the field. Where on the other hand, Alkhafaji, Abbass F (2003) stated that strategic management is comprises of formulation, implementation, and control in a dynamic environment. Strategic management is the process of assessing the corporation and its environment in order to meet the firm's long-term objectives of adapting and adjusting to its environment through manipulation of opportunities and reduction of threats. Whereas Courtney, Roger (2002) explained almost the same thing to mentioned on "Strategic Management for Voluntary Nonprofit Organizations." Routledge studies Courtney, Roger (2002) in the management of voluntary and non-profit organizations. On the other hand, Bowman and Asche (1987), 
stated that Strategic Management' as 'the process of strategic change' or as 'the process of making and implementing strategic decisions', 'strategic decisions' being those 'that determine the overall direction of an enterprise and its ultimate viability in light of the changes that may occur in its environments'.

Plotted graphically based on its market share (a measure of its competitive position relative to its peers) and industry growth rate (a measure of industry attractiveness) in each, on the concept of the corporation as a portfolio of business units, is applied. Giving summary in the growth-share matrix, which developed by the Boston Consulting Group around 1970. Based on the information given by Fortune 500, in 1979, one study estimated that 45 percents of the companies were using some variation of the matrix in their strategic planning. The framework given by the approach had helped companies to decide where to invest their resources, where Kiechel, W (2010), in Harvard Business Press express the terminology of "The Lords of Strategy", delivered a set of further explanation on: high market share, high businesses, low growth market share, low growth businesses, and which businesses to divest. The growth-share matrix was followed by G.E. multi factoral model, developed by General Electric. Furthermore, David (2006) explained that external strength and internal weakness can be vise-verse influenced and controlled. Therefore, using the IFE (Internal Factor Evaluation) Matrix to identify and evaluate strength and weakness of the organization in the business strategy is essential. In his book titled Strategic Management, the external factor uses EFE (External Factor Evaluation) Matrix as an analysis tool.

Every company and business requires a good management system, therefore enterprises and business objectives can be achieved. Ferrel et al. (2008) mentioned that management is the design process to achieve organizational goals using organizational resources effectively as well as environmental changes. Furthermore, Brewer \& Speh (2000), strategic management process includes five distinct but related development of the: (1) mission; (2) goal setting; (3) strategy development and selection; (4) strategy implementation and evaluation. Companies should always evaluate and weigh internal and external factors to be able to keep up with external development and competitive environment. According to David (2006), the purpose of the external factor analysis is to develop some opportunities that might be the strength of the company as a beneficial factor upon the external threat, and that statement supported by Triandharta and HaqueFawzi (2019), that the development of external factor analysis will give a strong influence to a company decision making process to gain profits. David (2006) explained that using the IFE (Internal Factor Evaluation) Matrix to identify and evaluate strength and weakness of the organization in the business strategy is essential.

IE Matrix can be divided into three major areas that describe the implication of the corporate strategies. According to Torlak and Sanal (2007), IE Matrix is based on twodimensional keys, as follow: (1) total weight of the IFE that put on the " $\mathrm{X}$ " axis: and (2) total weight of the EFE that put on the "Y" axis. Rangkuti (2009) explains that SWOT Analysis is to systematized various factors identification to formulate Corporate strategy. According to Sherman et al. (2007), SWOT Analysis compares the company's external and internal strength and weakness to ensure that the company has the internal capability to support the business growth. SWOT Analysis also compares the external opportunity and threat in a sense of sustainable growth business. Andrews (1965) in Gürel, (2017) stated that SWOT formulation offers a company a strategy that is based on external and internal factors analysis and evaluation. David (2006) has developed the four strategies of TOWS (the other way round of SWOT) Matrix that explained through ST, WT, WO, and SO Strategy. In fact, in the 1980s, the SWOT analysis also was used for SMEs' development 
and the creation of business and marketing plans. Heinz Weihrich (1982) in Gürel (2017), stated that TOWS Matrix for matching the environmental threats and opportunities had introduced by him. He matched the SWOT variables in a very systematic fashion. Furthermore, in the 1990's was also used in regional development, project formulation, and the social marketing of NGOs. Richard Dealtry (1992) in Gürel (2017), stated that he developed 'Dynamic SWOT Analysis' namely DSA. Dealtry (1992) developed SWOT as a dynamic project management process involving managers in the preparation and implementation of value-driven strategies using learning organization principles, ideas, and cycles. It starts with raw shock analysis and moves onward through group and threshold issues, decision analysis, and prioritizing SWOT attributes as a basis for taking executive action and tactical project management. On the other hand, concerning IFAS (Internal Factor Analysis Summary) and EFAS (External Factor Analysis Summary) tables, Thomas L. Wheelen and J. David Hunger (1993) in Gürel (2017), developed that them to deal with the criticism of SWOT. Therefore, SFAS Matrix summarizes strategic factors by combining the external factors from EFAS Table with the internal factors from IFAS Table. Possible alternative strategies can be generated by referring to EFAS and IFAS table in generating SWOT Matrix.

To perfect the results of the SWOT analysis, a four-step strategy from Boston Consulting Group is used. The BCG matrix was developed by Bruce Henderson in the 1970s. Because this Matrix was developed by the founder of Boston Consulting Group (BCG), this matrix is called the BCG Matrix which stands for Boston Consulting Group. Bruce Henderson is also the founder of the Boston Consulting Group (BCG), a leading global management consulting firm that was ranked the third best company to work on the Forbes version in 2014. This BCG matrix is also closely related to the product life cycle (Products life cycle) so it is often referred to as the Product Portfolio Matrix. Other names for the BCG Matrix include the BCG Growth-Share Matrix, the Boston Box, and the Portfolio Diagram (Portfolio Diagram).

BCG Matrix is a business analysis tool used to assist companies in considering growth opportunities with long-term strategic planning, and reviewing the company's product portfolio to make decisions to: (1) invest; (2) develop; or (3) stop their products. This BCG matrix also assists companies in determining the allocation of resources, as well as an analytical tool in: (1) brand marketing; (2) product management; (3) strategic management; and (4) Portfolio analysis.

The BCG matrix consists of matrices that are 2 rows $\mathrm{x} 2$ columns or consist of 4 cells (4 quadrants). The 4 cells represent the 4 categories of the company's product portfolio from 2 dimensions of business unit classification, namely Relative Market Share (relative market share) and Market Growth Rate (market growth rate).

\section{Research Methods}

The research conducted at BMT Beringharjo, the sharia non-bank microeconomic in Yogyakarta. By evaluating external and internal factors, the company develops a strategic plan. Whereas Kuncoro (2006) explained, that based on the research method can be classified by: (1) historical research; (2) descriptive research; (3) co-relational research; (4) causal-comparative research; and (5) experimental research. Descriptive data are collected through questionnaires with interviews. 
Techniques of data collection required is done through: (1) secondary data such as literature study by books and internet; and (2) primary data by a set of a questionnaire given to 4 (four) persons in the position of President Director, Marketing Director; HR Director, and Finance Director.

Research conduction begins with internal and external analysis of the company and SWOT methods to be analyzed, where SWOT analysis shows the strength of the business of BMT Bringharjo in its market penetration. The company's business attraction lies in its human development. Using the IE Matrix, it is founded that BMT Beringharjo competitive position is in Quadrant IV or Cell IV. Its result shows the position of growth. And strategies that need to be implemented are: (1) market penetration; (2) market development; (3) horizontal integration. However, implementation of some creative steps and innovation in facing the tough competition to become a winner is inevitable.

\section{Results and Discussion}

Evaluation of internal factors is used to determine the strength and weakness of BMT Beringharjo sharia non-bank micro-economic in Yogyakarta. BMT Beringharjo needs to apply some strategies to enhance strengths and reduce weaknesses in a sense to avoid loss. The Islamic moral-value is the catalyst that leverages BMT Beringharjo competitive advantage. Expansion of its services needs to be applied to develop its business coverage is. Eventually, its market is still limited, therefore BMT Beringharjo requires a larger capital investment to develop products and services.

Strategy evaluation needs to be done continuously to the company can adapt to its developments and changes in the environment which occurred. In this stage, the analysis process is carried out on external and internal factors of the Beringharjo BMT nonbank sharia microfinance institutions. The results and analysis will indicate in which position the BMT Beringharjo at the time the research was conducted. Strategy evaluation needs to be done continuously so that the company can adapt to developments and changes in the environment that occurs. In this stage, the analysis process is carried out on external and internal factors of the Beringharjo BMT non-bank Islamic microfinance institutions. The results and analysis will indicate in which position the BMT Beringharjo nonbank sharia microfinance institutions at the time the research was conducted.

Rangkuti (2006) stated that at each initial stage of a strategy formulation analysis framework, it does not merely consist of data collection activities only. But also there are two activities, namely: (1) classification; and (2) pre-analysis. At this initial stage, the data can be divided into two types, they are: (1) external data; and (2) internal data in determining what are the strengths, weaknesses, opportunities, and threats for BMT Beringharjo non-bank sharia microfinance institutions.

The tools used for evaluation are questions with the SWOT Analysis approach (strengths, weaknesses, opportunities, and threats). Previously it was started by getting the key success factor from the company, by conducting an initial in-depth interview. So we get several keys to success as a factor. The Key Success Factor or Beringharjo BMT is the basis used for SWOT analysis through external and then internal. With the following information as follows:

(1) External

\section{A. Opportunities}

1. The majority of Indonesia's population are Muslims;

2. BMT is not affected by the 1998 and 2008 monetary crisis;

3. BMT is proven tough (has a fanatical market or captive market); 
4. BMT helps Government programs indirectly;

5. Most Indonesian people are in the economic strata of SMEs;

6. The system of sharia financial institutions is not affected by the monetary crisis;

7. The system of sharia financial institutions is most suitable for the people in this economic' strata.

B. Threats

1. The impact of competition with international financial institutions or globalization on national financial institutions;

2. The entry of large-scale sharia banking with non-Muslim owners who provide very low loan costs (cheap) because it can reach the economics' of scale;

3. Unstable domestic political and security situation;

4. Indonesian laws and regulations that do not favor BMT;

5. Indonesian agreements on the WTO and ACFTA and following BRIC;

6. Very rapid technological developments (in terms of ATM, SMS, internet banking services).

7. There is no shared database for criminal creditors.

(2) Internal

A. Strengths

1. BMT has a good reputation;

2. BMT has simple but solid management;

3. BMT has independence because it grows and develops from-by-for the surrounding community itself;

4. BMT is very familiar with its sharia market needs;

5. BMT is very familiar with the characteristics of its creditors or clients;

6. BMT has the ease of processing compared to conventional banking in general;

7. BMT focuses on micro small and medium enterprises or SMEs.

B. Weaknesses

1. BMT is almost always not enough capital for business development;

2. BMT often has less reliable HR;

3. BMT is very lack promotion;

4. BMT service products are still limited;

5. There is no IT-based shared database for criminal creditors;

6. Many BMT cases cannot be completed because of the limited capacity of Indonesian law enforcement authorities;

7. There is no legal certainty in the form of a law that can protect BMT's obligations

After the key success factors of the company are obtained, the next step is to adapt them to each of the SWOT elements (strengths, weaknesses, opportunities, and threats) that refer to: (1) strengths; (2) weaknesses; (3) opportunity; and (4) threats. Selected respondents were from all top management levels of the Beringharjo Baitul Maal wa Tamwil company or BMT in Yogyakarta. 


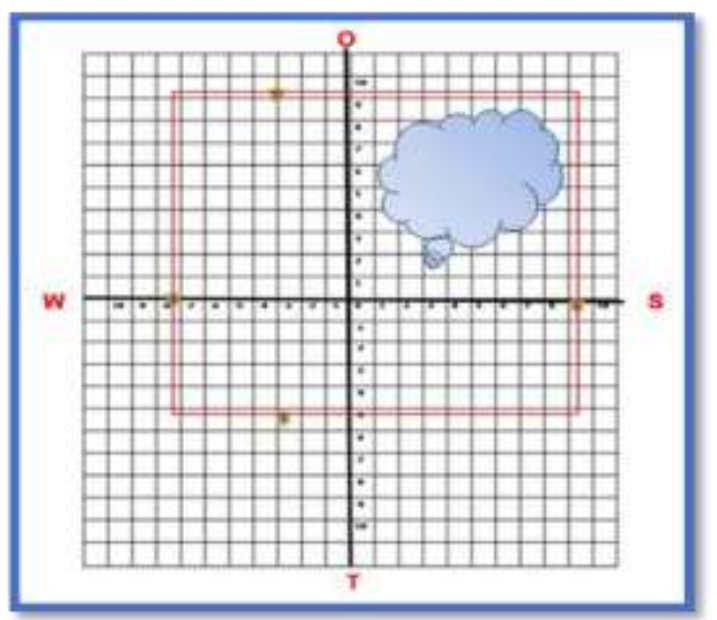

Source: Data Processed (2011)

Figure 1. BMT SWOT Analysis Results Beringharjo, Yogyakarta, 2011

The result from its EFE Matrix (from Opportunity and Threats) is 3,9500, following with the result of IFE Matrix (from Strength and Weakness) is 4, 1676. Both are obtained from questionnaires given after FGD (Focus Group Discussion) was conducted to get 14 items of its key success factors. Evaluation of both matrixes mentioned is to identify elements of Opportunity and Threats of BMT Beringharjo sharia non-bank microeconomic in Yogyakarta. Knowing both elements mentioned, are necessary to win a competition through the right strategy.

As a small financial institution, sharia non-bank micro-economic during the injury time after sub-prime mortgage case in America and allies, BMT Beringharjo in Yogyakarta, Indonesia, has to face de-industrialization and economy dynamic slow-down situation. Mapped in Cell I, the total weight of EFE and IFE of BMT Beringharjo has meanings of growing and to build. Strategies of "grow" as intensive, comprises of: (1) market development; (2) market penetration; and (3) product development, and strategies of "build" as integration, comprises of: (1) forward integration; (2) backward integration; and (3) horizontal integration.

The result of the IE Matrix is a combination of intensive and integration strategies leads: (1) SO strategies that may be the promotion of proper conduct, participate in the sharia non-bank micro-economic in Yogyakarta, producing internet-related equipment, and launch various programs and services with competitive prices; (2) ST strategies that may be the quality improvement, pricing re-set, human resource training improvement; (3) WO strategies may include service expansion to the areas' potential of shariah non-bank micro-financial institution, and alliances or a merger with other similar companies; and (4) WT strategies may include cost efficiency of both operational and services. 


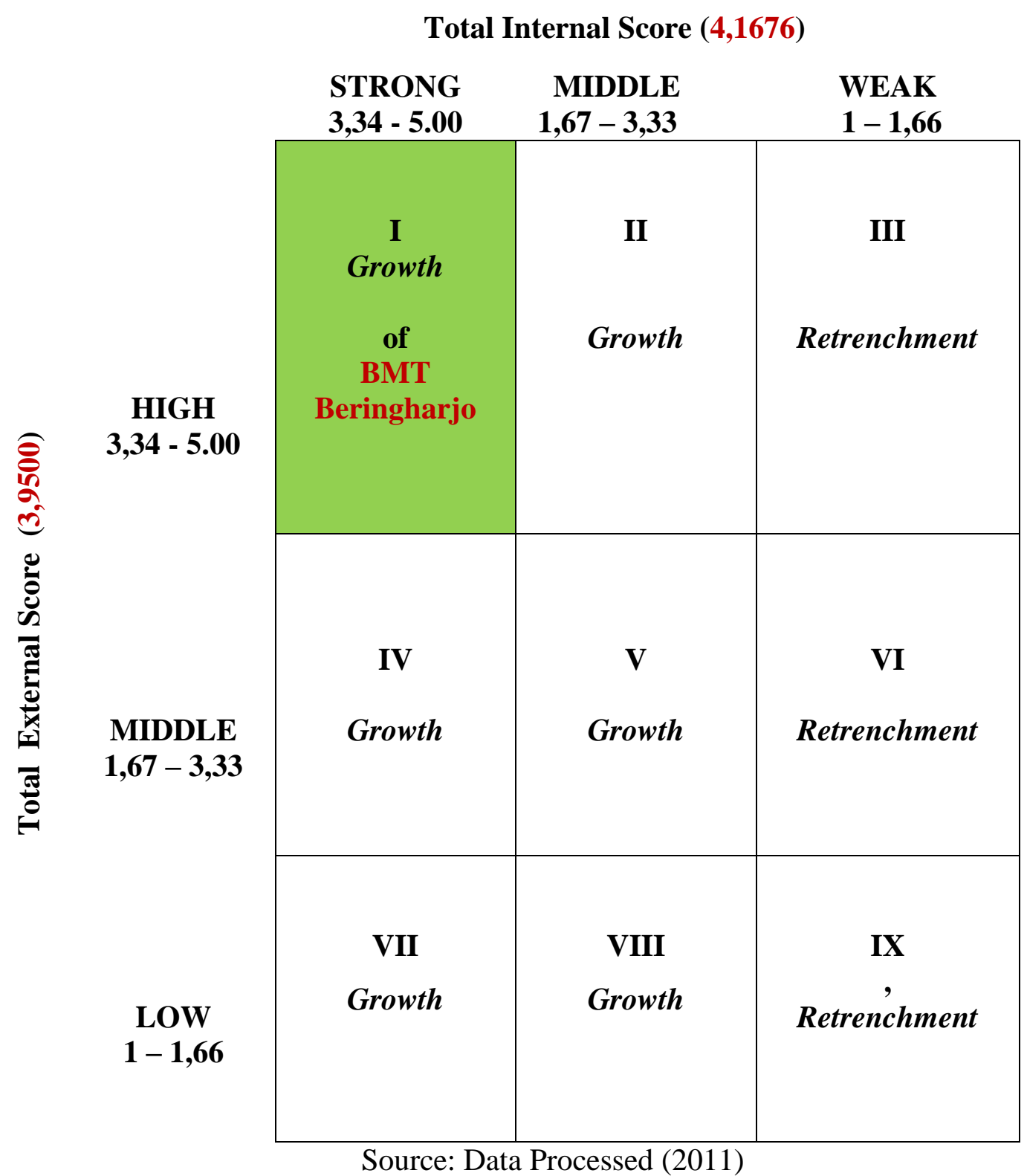

Figure 2. Internal-External Matrix or EI of the Beringharjo BMT Sharia Microfinance Institution

Furthermore, as a small financial institution, BMT Beringharjo sharia non-bank microeconomic in Yogyakarta needs to provide more training to improve the quality of human resources, more person-to-person 'home-care' services to customers, reduce operating cost to pursue its competitive advantage. 


\section{Conclusion}

In conclusion, mapped in Cell I of its IE (Internal-External) Matrix, BMT Beringharjo as a sharia small financial institution can implement both intensive and integration strategies.

(1) IFE Matrix of BMT Beringharjo as a sharia small non-bank financial institution in Yogyakarta that mapped in a strong position that has a weighted value of 4,1676, and EFE Matrix that result in a weighted value of 3,9500 for its external factors;

(2) Resulting from the highest score and mapped in Cell I obtain a meaning that penetration strategy to the attractive market is strongly needed. Therefore, an appropriate formulation of IE (Internal and External condition) strategy, as well as the assessment of the competition condition, needs to be scrutinized and implement prudently.

\section{References}

Alkhafaji, Abbass F. (2003). Strategic Management: Formulation, Implementation, and Control in a Dynamic Environment. New York: Routledge.

Brewer, P.C., \& Speh, T,W. (2000). Using Balance Scorecard to Measure Supply Chain Performance. Journal of Business Logistics, Vol. 21, Issue 1, pp. 75.

Courtney, Roger (2002). Strategic Management for Voluntary Nonprofit Organizations. Routledge studies in the management of voluntary and non-profit organizations. London: Psychology Press. p. 8.

David, F. R. (2006). trategic Management: Concept and Case. Atlanta: Prentice Hall.

Ferrel, OC; Ferrel, L; and Hirt, G. (2008). Business a Changing World. Boston: McGraw Hill.

Gürel, E .(2017). Swot Analysis: a Theoretical Review. Journal of International Social Research. 10(51): pp. 994-1006.

Kiechel, Walter. (2010). The Lords of Strategy. Messacutes: Harvard Business Press.

Kuncoro, M. (2006). Strategi Bagaimana Meraih Keunggulan Kompetitif. Jakarta: Erlangga.

Lakshmi, P., and S. Visalakshmi. (2013). Impact of Cooperatives in Financial Inclusion \& Comprehensive Development. Journal of Finance and Economics 1.31 (3), pp 4953.

Nag, R.; Hambrick, D. C.; Chen, M.-J. (2007). What is Strategic Management, Really? Inductive Derivation of a Consensus Definition of the field. Strategic Management Journal. Vol.28, No.9, p.935-955.

Orji, M. G., and Yakubu, G.N. (2020). Effective Stress Management and Employee Productivity in the Nigerian Public Institutions; A Study of National Galary of Arts, Abuja, Nigeria. Budapest International Research and Critics Institute-Journal (BIRCI-Journal). P. 1303-1315.

Pfeffer, Jeffrey. (2009). The External Control of Organizations: a Resource Dependence Perspective. Stanford: Stanford Business Books.

Rangkuti, F (2006). Analisis Swot Teknik Membedah Kasus Bisnis. Jakarta: Gramedia Pustaka Utama.

Rangkuti, F. (2009). Teknik Membedah Kasus Bisnis: Analisis SWOT. Jakarta: Gramedia.

Sherman, H., Rowley., D.J., and Armandi, B.R. (2007). Developing a Strategic Profile: the Pre-planning Phase of Strategic Management. Business Strategy Series. Vol. 8 No. 3, pp. 162-171. 
Siregar, F.H., (2020). Relationship Emotional Intelligence with Conflict Management in Employees of PT. Aspacindo Kedaton Motor. Budapest International Research and Critics Institute-Journal (BIRCI-Journal). P. 1251-1261.

Sitanggang, S. N., et al. (2020). Analysis ofthe Influence ofManagerial Ownership, Audit Quality and Audit Committee on Income Management (Study on Manufacturing Companies in the Consumer Goods Sector Listed on the Indonesia Stock Exchange 2014-2018). Budapest International Research and Critics Institute-Journal (BIRCIJournal). P. 2521-2533.

Triandharta, R., and Haque-Fawzi, M.G. (2019). Analisis Strategi Pemasaran Produk KPR iB dengan Akad Musyarakah Muttanaqishah (MMQ): Studi Pada PT Bank Frwrd. Tbk. Jurnal Ilmu Manajemen \& Ekonomika, 11 (1), pp. 35-43.

Torlak, N.G and Sanal, M. (2007). David's Strategy Formulation Framework in Action: The Example of Turkish Airlines on Domestic Air Transportation. Istanbul Ticaret Üniversitesi Fen Bilimleri Dergisi Y1l: 6 Sayı:12 Güz 2007/2 s. 81-114. 